\title{
Bioaerosols in an Underground Tourist Trail
}

\author{
Lukasz Wlazło1, Martyna Kasela², Bożena Nowakowicz-Dębek ${ }^{3 *}$, \\ Mateusz Ossowski ${ }^{1}$, Anna Malm²
}

\begin{abstract}
${ }^{1}$ Department of Animal Hygiene and Environmental Hazards, University of Life Sciences in Lublin, Lublin, Poland
${ }^{2}$ Department of Pharmaceutical Microbiology, Medical University of Lublin, Lublin, Poland

${ }^{3}$ Laboratory of Environmental and Occupational Hazards, University of Life Sciences in Lublin, Lublin, Poland
\end{abstract}

Received: 27 October 2019

Accepted: 14 January 2020

\begin{abstract}
Cultural heritage objects, often aged and vulnerable, are at a particularly high risk of microbial pollution. Enzymatic activity of bacteria and fungi might lead to the damage of precious antique objects, while microbial pathogenicity and immunogenicity can pose a threat to the health of staff and visitors. Therefore, monitoring the microbiological contamination of cultural heritage objects is necessary, especially in the case of unique objects, like tourist trails located underground. We have evaluated the concentration and diversity of microorganisms present in the air and surfaces of the Lublin Underground Trail located in Poland. We have found the prevalence of bacterial species being a part of the human microbiota in the analysed air. The average fungal contamination of the air was low $\left(337 \mathrm{CFU} / \mathrm{m}^{3}\right.$ ), but we have identified species of high immunogenicity and those contributing to biodeterioration. Microclimatic parameters were considered as favourable for microbial growth, which emphasizes the role of adequate heating and ventilation air conditioning systems providing sufficient air quality in cultural heritage objects.
\end{abstract}

Keywords: bioaerosol, indoor air, historic buildings, cultural heritage, biodeterioration

\section{Introduction}

Cultural heritage objects are at a particularly high risk of microbial pollution due to their location in historic buildings. Old buildings are often unadapted to the role of libraries, archives and museums, thus providing insufficient conditions to store art works vulnerable for the destruction caused by enzymatic activity of microorganisms during the process called biodeterioration. Long-term exposure to biological agents might lead to allergies, asthma, allergic rhinitis,

*e-mail: bozena.nowakowicz@up.lublin.pl inflammation of the sinuses and bacterial or fungal infections in immunocompromised people [1]. The role of monitoring the microbiological quality of the air is emphasized by the fact that people spend up to $90 \%$ of their time at home or at work [2].

Air constitutes a vector of bacteria, fungi, and viruses, as well as their metabolic compounds like endotoxins, mycotoxins and MVOCs (volatile organic compounds). Dust plays a key role in transmitting microorganisms by air, because it acts as a carrier of organic particles. Bioaerosols - all organic particles suspended in the air - represent even one third of the indoor air pollutants [1]. Bioaerosol particles are characterized by a large variation in size (from $0.5 \mu \mathrm{m}$ of bacterial cells to even $25 \mu \mathrm{m}$ of fungal 
spores), as well as multiple microbial species in different concentrations [3].

The presence of a small amount of organic matter, i.e., in dust, is adequate for the growth of fungi and bacteria. The factors that favour the growth of bacteria and filamentous fungi include: high water activity, increased levels of carbon dioxide, insufficient ventilation, lack of appropriate air exchange systems, increased humidity and temperature fluctuations [1, 4]. Increased humidity along with a high level of salinity leads to the development of halotolerant and halophilic microorganisms that are responsible for a very fast corrosion process that destroys inorganic materials. The activity of this group of microorganisms is observable in a form of characteristic salt efflorescence on infected surfaces [5]. The most easily observed signal indicating biodeterioration is also surface change of material, including fiber damage, structural defects, visible growth of microorganisms and decolourisation [4].

The selection of an HVAC system has critical significance both for maintaining the proper microclimatic conditions that reduce microbial contamination of the air as well as for protecting historic objects against biodeterioration. In the case of HVAC systems, constant monitoring of the technical condition of the system and its valid operation is equally important, because even the inappropriate direction and the speed of airflow can increase the level of microbiological contamination of the indoor air. It was also established that a constant temperature significantly limits the number of bacteria in the air [6].

Monitoring the microbiological quality of the air allows us to identify factors potentially harmful to human health in specific work places, which is also an issue highlighted by other authors [7]. For those reasons, sources, concentration and the diversity of microorganisms in cultural heritage objects should be determined.

Our aim was to determine the concentration and diversity of microorganisms present in the air and on surfaces of the Lublin Underground Trail as well as to discuss the potential sources of identified microorganisms and their role in the biodeterioration of cultural heritage objects.

\section{Material and Methods}

\section{Sampling Site}

The underground tourist trail is currently a very popular attraction in Lublin (Poland). This 280-m (918,6 feet) long maze was created through a connection of restored cellars, located over a dozen meters below ground; the oldest cellars were built in the $16^{\text {th }}$ century. Gravity ventilation ducts are located along the entire trail, but there is no heating and air conditioning. One of the main attractions is wooden maquettes visualizing the development of the city. In 2017 a total of 27,647 tourists visited the trail. The average number of tourists per month was $2304 \pm 1242$ : the lowest noted for January (576) and the highest for May (4098). The Lublin Underground Trail consists of one main corridor connecting 14 small chambers. Side chambers, however, are not separated from the corridor. Measuring points were located at equal distances from each other (approximately $50 \mathrm{~m}$ ) to ensure the best reflection of the average concentration of microorganisms in the air of the entire trail. Because of the age of the studied place and underground location, the tourist trail creates unique environmental conditions.

\section{Sampling and Analytical Methods}

Microbiological analysis of the air was carried out using the collision method and a Microbio MB1 microprocessor air sampler (De Ville Biotechnology, France). All measurements were repeated twice. Samples of the air (50 L) were collected in seven selected points at a height of $1.5 \mathrm{~m}$ above the floor. To determine the total number of bacteria and fungi in the analyzed air we used tryptic soy agar and Sabouraud medium (BTL Ltd, Poland). The presence of staphylococci and Gram-negative rods was determined using mannitol salt agar and MacConkey medium (BTL Ltd, Poland), respectively. Plates were incubated for $24 \mathrm{~h}$ at $37^{\circ} \mathrm{C}$, except Sabouraud medium, which was incubated for 5 days at $25^{\circ} \mathrm{C}$. After the incubation, the number of bacterial and fungal colonies were counted. The results were corrected according to the conversion tables provided by the air sampler manufacturer and inserted into the following formula, and the concentration of microorganisms in the air were presented as colony forming units per $1 \mathrm{~m}^{3}$ of air $\left(\mathrm{CFU} / \mathrm{m}^{3}\right)$ :

$\mathrm{X}=(\mathrm{a} \times 1000) / \mathrm{V}$, where:

a - the sum of microbial colonies grown on a given medium

$\mathrm{V}$ - the volume of air sample (L)

The type of fungal contamination of surfaces was determined by swabbing wooden maquettes, walls of the corridor and cellars, and the openings of ventilation ducts with sterile cotton swabs. Swabs were inoculated on Sabouraud medium and incubated in the conditions mentioned before. The following microclimatic parameters were also measured: relative humidity (8706 Psychrometer, AZ Instrument Corp.), air movement, temperature (Hot Wire Anemometer AM-4204, Lutron Electronic) and the concentration of carbon dioxide (MX6 iBrid Six-Gas Monitor, Industrial Scientific). Species identification of bacteria was conducted based on Gram staining, production of catalase, coagulase, cytochrome oxidase and biochemical API tests (API 20E/CORYNE/STAPH/20 STREP, BioMérieux). The fungi were identified both on the basis of their macroscopic and microscopic characteristics using the key for fungi identification [8]. The correlation 


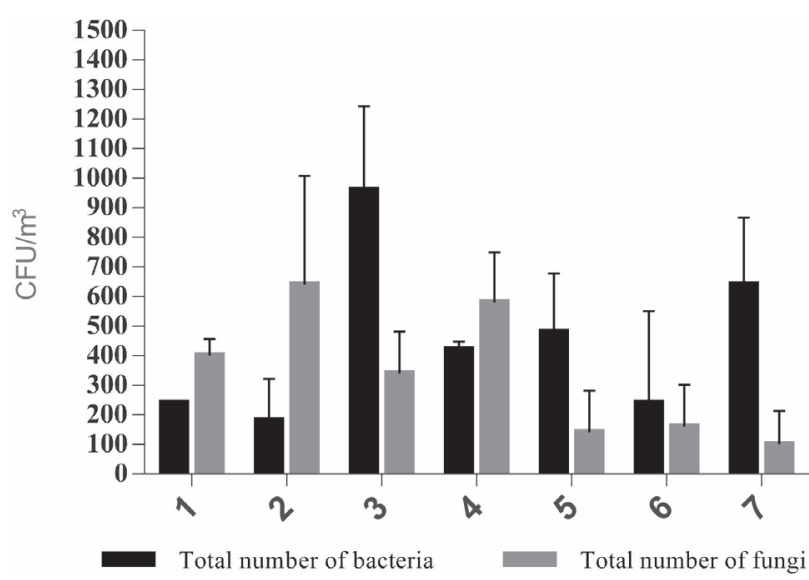

Fig. 1. Total number of bacteria and fungi in the air of the Lublin Underground Trail (mean $\pm \mathrm{SD})$.

between the number of microorganisms in the air and microclimatic conditions was determined using Spearman's test and Statistica 13 software (StatSoft Inc.).

\section{Results and Discussion}

\section{Total Number of Bacteria and Fungi}

The microbial load in the air of historic old buildings depends on many factors, including humidity, type of ventilation, geographic location, the presence of antique objects and the number of visitors. We have assumed that the underground location of the tourist trail promotes the accumulation of water, therefore microbial contamination of the air would be significant. However, we found that the average number of bacteria isolated from the air of the Lublin Underground Trail - 466 $\pm 247 \mathrm{CFU} / \mathrm{m}^{3}$ - was comparable to that found in other studies (Fig. 1). Similar results were found in the air of museum rooms $-340-560 \mathrm{CFU} / \mathrm{m}^{3}$ [9], as well as archives and library rooms $-110-470 \mathrm{CFU} / \mathrm{m}^{3}[10]$, both located in Poland. In four out of seven measurement points, the number of bacteria were at least twice as

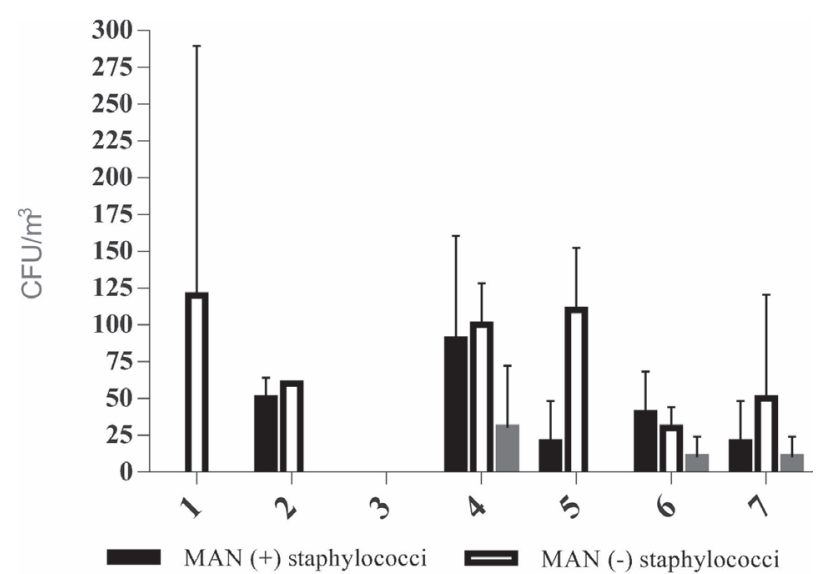

Enterobacteriaceae

Fig. 2. Number of mannitol-positive and mannitol-negative staphylococci, and number of Enterobacteriaceae in the air of the Lublin Underground Trail (mean \pm SD).

high as the number of fungi. The prevalence of bacteria in the indoor air bioaerosol is commonly found in many studies. Skóra, Gutarowska, and Pietrzak [10] noted that bacteria accounted for $56-84 \%$ of the bioaerosol of Polish archives and library rooms. Low average fungal contamination $\left(337 \pm 200 \mathrm{CFU} / \mathrm{m}^{3}\right)$ was probably caused by the lack of airflow in the vents, depriving the environment of access to the atmospheric air, which is the main source of these microorganisms (Table 1).

The number of mannitol-positive staphylococci varied $\left(0-90 \mathrm{CFU} / \mathrm{m}^{3}\right)$, but in six out of seven measurement points this was higher than the number of mannitol-negative ones (Fig. 2). Genus Staphylococcus is one of the indicators of air quality, including contamination with potentially pathogenic species like S. aureus [11]. The high concentration of staphylococci in the indoor air is most often caused by emissions from the human upper respiratory tract [12], thus visitors might increase the bacterial air contamination. The presence of Gram-negative rods were noted only in three measurement points and the concentration in the Lublin Underground Trail air was low $\left(0-30 \mathrm{CFU} / \mathrm{m}^{3}\right)$.

Table 1. Concentrations of $\mathrm{CO}_{2}$ and microclimatic parameters in the Lublin Underground Trail.

\begin{tabular}{|c|c|c|c|c|}
\hline Air sample & $\mathrm{CO}_{2}(\%$ vol. $)$ & Temperature $\left({ }^{\circ} \mathrm{C}\right)$ & Relative humidity $(\%)$ & Air movement (m/s) \\
\hline 1 & 0.06 & 17.1 & 63 & 0 \\
\hline 2 & 0.06 & 16.2 & 63 & 0 \\
\hline 3 & 0.03 & 15.3 & 66 & 0 \\
\hline 4 & 0.06 & 13.5 & 85 & 0 \\
\hline 5 & 0.06 & 14.5 & 62 & 0 \\
\hline 6 & 0.06 & 12.0 & 58 & 0 \\
\hline 7 & 0.06 & 13.5 & $65.1 \pm 8.5$ & 0 \\
\hline
\end{tabular}




\section{Bacterial and Fungal Species}

The main source of microorganisms in indoor air is outdoor air, as well as people and animals. People spread bacteria and fungi by moving, coughing or talking; they can also transfer environmental microorganisms on their clothes or shoes [13]. We have found presence of multiple bacteria species in the Lublin Underground Trail that belong to the physiological human microbiota and usually inhabit the skin, mucous membranes of the oral cavity or the upper respiratory tract (Table 2). Being a component of the human microbiota, Staphylococcus spp., Corynebacterium spp., Micrococcus spp. and Kocuria spp. are often isolated from indoor air [9, 14]. It is also well known that the high density of streptococci in bioaerosols can be found in crowded rooms [15]. Part of identified commensal microorganisms act as opportunistic pathogens, and in high concentrations may pose a threat to human health, which is confirmed by the examples of diseases reported by different authors (Table 2). However, these bacterial diseasecausing capabilities activate in the case of the hosts' immune system disorders or the presence of serious comorbidities, thus the probability of infection among the staff and visitors of the Lublin Underground Trail is low. On the other hand, we observed salt efflorescence on the walls of the main corridor and side rooms as well as water condensation. Such conditions - high salinity and humidity - facilitate biodeterioration and provide an environment suitable for the development of halophilic and halotolerant microorganisms, like genus Staphylococcus and Micrococcus able to grow in $15 \%$ salinity [16-18].

All of the fungal species isolated from the analysed air are being commonly found as part of an outdoor bioaerosol, and their pathogenicity is mainly connected with the high concentration in the air, the presence of immunogenic particles and/or the

Table 2. Characteristics of bacteria isolated from the air of the Lublin Underground Trail.

\begin{tabular}{|c|c|c|c|}
\hline Bacterial species & Possible sources & Pathogenicity & Biodeterioration abilities \\
\hline Propionibacterium avidum & $\begin{array}{l}\text { skin of groins, armpits and crotch } \\
{[19]}\end{array}$ & NDA & none [19] \\
\hline Cellulomonas spp. & soil [20] & NDA & decomposition of cellulose [4] \\
\hline $\begin{array}{l}\text { Cellulosmicrobium cel- } \\
\text { lulans }\end{array}$ & soil [20] & NDA & $\begin{array}{l}\text { biocorrosion of mineral building } \\
\text { materials [4] }\end{array}$ \\
\hline Brevibacterium spp. & water [21] & NDA & $\begin{array}{l}\text { deterioration of concrete, brick, } \\
\text { glass [4] }\end{array}$ \\
\hline Leifsonia aquatica & water [22] & acute septicemia [22] & $\begin{array}{c}\text { NDA; Leifsonia poae: deterioration } \\
\text { of wooden altar [23] }\end{array}$ \\
\hline $\begin{array}{l}\text { Staphylococcus } \\
\text { haemolitycus }\end{array}$ & skin $[24,25]$ & neonatal sepsis [24] & $\begin{array}{c}\text { deterioration of photographic paper } \\
{[26]}\end{array}$ \\
\hline Staphylococcus hominis & skin of arms, legs, trunk $[27,28]$ & general infections, sepsis [29] & $\begin{array}{c}\text { deterioration of photographic paper } \\
{[26]}\end{array}$ \\
\hline Staphylococcus capitis & skin $[30]$ & prosthetic joint infections [31] & deterioration of stone [26] \\
\hline Staphylococcus spp. & skin and mucous membranes [14] & dependent on the species & $\begin{array}{l}\text { deterioration of stone and murals } \\
\text { [32] }\end{array}$ \\
\hline Micrococcus spp. & skin and mucous membranes [14] & NDA & $\begin{array}{c}\text { deterioration of stone and murals } \\
\text { [32] }\end{array}$ \\
\hline Kocuria spp. & skin, mucosa and oropharynx [33] & $\begin{array}{c}\text { endocarditis, catheter-related } \\
\text { bacteraemia }[33,34]\end{array}$ & NDA \\
\hline $\begin{array}{l}\text { Pseudomonas oryzihab- } \\
\text { itans }\end{array}$ & water and soil [35] & $\begin{array}{c}\text { catheter-related nosocomial } \\
\text { infections, skin and soft tissue } \\
\text { infections }[36,37]\end{array}$ & $\begin{array}{c}\text { deterioration of stone and murals } \\
\text { [32] }\end{array}$ \\
\hline Alcaligenes spp. & water and soil [38] & NDA & $\begin{array}{c}\text { corrosion of metals, metal alloys, } \\
\text { plant and animal fibers, paint } \\
\text { coatings [39] }\end{array}$ \\
\hline Aeoroccus viridans 2 & upper respiratory tract $[40,41]$ & $\begin{array}{c}\text { endocarditis, osteomyelitis, } \\
\text { meningitis, septic arthritis [40, } \\
41]\end{array}$ & NDA \\
\hline $\begin{array}{l}\text { Streptococcus constellatus } \\
\text { sp. constellatus }\end{array}$ & $\begin{array}{l}\text { oral cavity, gastrointestinal tract } \\
\qquad[42,43]\end{array}$ & $\begin{array}{l}\text { potential role in chronic } \\
\text { periodontitis }[44]\end{array}$ & NDA \\
\hline
\end{tabular}

Note: NDA - no data available 
production of mycotoxins. Special attention should be paid to filamentous fungi that belong to primary colonizers - fungi able to grow in the lowest water activity environment, i.e., Penicillum expansum [45-47]. We found that most of the isolated fungal species were theoretically capable of producing mycotoxins (Table 3). As previously shown, Aspergillus flavus can produce aflatoxin B1 or/and B2 and is an etiological factor of aspergillosis [48, 49]. The presence of genus Aspergillus was found in the air, and swab samples from the walls and ventilation ducts (A. versicolor, A. niger, A. flavus). For some species, i.e., $A$. versicolor, the environmental factor triggering the production of mycotoxins is the high humidity of colonized materials [47]. Other signal for the production of the fungal secondary metabolites is periodically unfavorable microclimatic conditions $[50,51]$, thus future studies about the pathogenicity of fungi in the indoor air should cover longer periods of time and consider the presence of mycotoxins in the air.

We found the presence of Cladosporium spp. in all of the air and swab samples; it was also the only species colonizing the wooden maquettes. Cladosporium spp. has very low toxicity, but high immunogenicity: ten different antigens have been described so far. Longitudinal exposition to Cladopsporium spp. spores might lead to the development of allergy and asthma $[52,53]$. According to Chmiel, Frączek and Grzyb [54], the prevalence of one fungal species in the bioaerosol and the longitudinal exposition might be a cause of adverse health effects. Although the fungi concentration in our studies was low, other authors highlight the role of the immunogenicity of identified species. Gutarowska [55] found that $40 \%$ of the inhabitants of mouldy buildings had increased levels of $\operatorname{IgE}$ antibodies. Similarly, Wiszniewska et al. [56] noticed that $30 \%$ of the employees of the National Museum in Warsaw were allergic to at least one of the filamentous fungi: $13 \%$ to Cladosporium spp., $11 \%$ to Penicillium spp., $9 \%$ to Alternaria spp. and $9 \%$ to Aspergillus spp. Fungal species present in bioaerosol of the Lublin Underground Trail were commonly found in other historical buildings in Poland [50], and were considered by some authors to be indicators of microbial air pollution ( $A$. niger, A. versicolor, C. macrocarpum, C. herbarumgenera, Penicillium spp. and Rhizopus nigrans), [9].

\section{Microclimatic Conditions}

Lack of air flow in all measurement points testifies to the ineffectiveness of ventilation present in the tested location (Table 1). Appropriate moisture insulation of a building along with the implementation of ventilation or air conditioning systems guarantee the stability of microclimatic parameters $[1,16]$. On the other hand, in the case of historical buildings the airflow rate itself could be a critical factor because rapid air movement enables the microorganisms to transfer and displace between different environments [54]. The average air temperature in the Lublin Underground Trail was $14.6^{\circ} \mathrm{C}$. The temperature range $18-32^{\circ} \mathrm{C}$ is considered to be favourable for the growth of most filamentous fungal species in the moderate climatic zone [55]. Optimum temperature for the growth of cellulitic fungi (14$15^{\circ} \mathrm{C}$ ) evaluated by Szostak-Kot [57] is similar to the temperature measured in our studies, which explains the intensive biodeterioration of wooden maquettes. Temperature of the air of the Lublin Underground Trail was not only sufficient for microbial growth, but had a potential to stimulate the production of mycotoxins. Also, the humidity (58-85\%) allowed for the growth of moulds as well the development of a biodeterioration process, which has also been observed by other authors [54, 58]. In our studies, the consequences of dampness were visible as water condensation on the walls along with the presence of salt efflorescence. The concentrations of carbon dioxide did not exceed the permissible concentration in enclosed spaces $(0.1 \%)$ as set by WHO [59].

We have not found any correlation between temperature and relative humidity of the analyzed air and microbiological parameters in all measurement points $(\mathrm{n}=7)$ : total number of bacteria $\left(\mathrm{r}_{\mathrm{s}}=-0.18\right.$, $p=0.71$ and $\left.\mathrm{r}_{\mathrm{s}}=-0.17, p=0.71\right)$, total number of fungi $\left(\mathrm{r}_{\mathrm{s}}=0.49, p=0.26\right.$ and $\left.\mathrm{r}_{\mathrm{s}}=-0.19, p=0.68\right)$, number of mannitol-positive staphylococci $\left(\mathrm{r}_{\mathrm{s}}=-0.43, p=0.34\right.$ and $r_{s}=0.06, p=0.9$ ), number of mannitol-negative staphylococci $\left(\mathrm{r}_{\mathrm{s}}=0.32, p=0.49\right.$ and $\left.\mathrm{r}_{\mathrm{s}}=0.58, p=0.17\right)$ and number of gram-negative bacilli $\left(\mathrm{r}_{\mathrm{s}}=-0.59, p=0.16\right.$ and $\left.r_{\mathrm{s}}=-0.13, p=0.79\right)$.

Table 3. Fungi isolated from the surfaces and the air of the Lublin Underground Trail.

\begin{tabular}{|c|c|c|c|}
\hline \multicolumn{4}{|c|}{ Fungi isolated from the surfaces } \\
\hline Room walls & Corridor walls & Ventilation ducts & Wooden maquettes \\
\hline Aspergillus versicolor & Cladosporium spp. & \\
Aspergillus flavus & Paecilomyces spp. & Paecilomyces spp. \\
Cladosporium macrocarpum & Ulocladium spp. & Cladosporium spp. \\
Ulocladium spp. & Fusarium spp. & Cladosporium spp. \\
Phoma spp. & Mucor spp. & \\
Rhizopus oryzae & Aspergillus niger & & \\
\hline \multicolumn{2}{|c|}{ Fungi isolated from the air } \\
\hline Rhizopus oryzae, Penicillium expansum, Mucor spp., Aspergillus flavus, Penicillium rhizogenum, Cladosporium spp.
\end{tabular}




\section{Conclusions}

Monitoring the microbiological quality of the air of cultural heritage objects ensures the safety of historic buildings, workers and visitors. Introducing adequate ventilation systems provides desired relative humidity and air temperature. The appropriate microclimatic parameters of the environment not only limit the growth of potentially harmful and toxicogenic fungi, but also slow the biodeterioration process. Analysis of the air of the Lublin Underground Trail showed that people are the main reservoir of isolated bacterial species, because the air itself is an environment inimical for the growth of bacteria and can only lead to their transmission. Based on this observation, the number of visitors could be a main factor increasing the bacterial air contamination levels in such cultural heritage objects. Specific environmental conditions present in the Lublin Underground Trail - lack of air movement caused by insufficient ventilation - lead to the accumulation of biological agents in the air, creating risk for the health of people in the case of long-term exposure or immune system impairment. Undoubtedly, the introduction of an HVAC system would help to maintain desirable microclimatic conditions in order to protect inorganic and organic materials from biodeterioration. Future studies concerning the assessment of exposure to biological agents should focus on determining the number of immunogenic and potentially toxigenic species of fungi in indoor air as well as investigate the influence of the number of visitors in historical buildings on the concentration of bioaerosol.

\section{Conflict of Interest}

The authors declare no conflict of interest.

\section{References}

1. CARLO D.E., CHISESI R., BARRESI G., BARBARO S., LOMBARDO G., ROTOLO V., SEBASTIANELLI M., TRAVAGLIATO G., PALLA F. Fungi and bacteria in indoor Cultural Heritage environments: microbial-related risks for artworks and human health. Environ. Ecol. Res. 4 (5), 257, 2016.

2. GOŁOFIT-SZYMCZAK M., ŁAWNICZEK-WAŁCZYK A., GÓRNY R.L. Bioaerosols in indoor workplaces hazards and their sources. Bezp. Pr. Nauk. Prakt. 3, 9, 2013 [In Polish].

3. OGÓREK R., PLĄSKOWSKA E. The mycological analysis of air in selected public rooms. Preliminary study. Med. Mycol. 18 (1), 2, 2011.

4. PIOTROWSKA M., OTLEWSKA A., RAJKOWSKA K., KOZIRÓG A., HACHUŁKA M., NOWICKAKRAWCZYK P., WOLSKI G.J., GUTAROWSKA B., KUNICKA-STYCZYŃSKA A., ŻYDZIK-BIAŁEK A. Abiotic determinants of the historical buildings biodeterioration in the former Auschwitz II-Birkenau concentration and extermination camp. PLoS ONE. 9 (10), e109402, 2014.

5. ADAMIAK J., OTLEWSKA A., GUTAROWSKA B., PIETRZAK A. Halophilic microorganisms in deteriorated historic buildings: insights into their characteristics. Acta Biochim. Pol. 62 (2), 335, 2016.

6. LIU Z., MA S., CAO G., MENG C., HE B.J. Distribution characteristics, growth, reproduction and transmission modes and control strategies for microbial contamination in HVAC systems: A literature review. Energy Build. 177, 77, 2018.

7. GĘBAROWSKA E., PUSZ W., KUCIŃSKA J., KITA W. Comparative analysis of airborne bacteria and fungi in two salt mines in Poland. Aerobiologia. 34 (2), 127, 2018.

8. WATANABE T. Pictorial atlas of soil and seed fungi: morphologies of cultured fungi and key to species. $2^{\text {nd }}$ ed.; Boca Raton, New York, NY: CRC Press, 2002.

9. SKÓRA J., ZDUNIAK K., GUTAROWSKA B., REMBISZ D. Harmful biological agents at museum workposts. Med. Pr. 63 (2), 153, 2012 [In Polish].

10. SKÓRA J., GUTAROWSKA B., PIETRZAK K. Microbiological hazards in archives and libraries. Bezp. Pr. Nauk. Prakt. 6, 22, 2013 [In Polish].

11. WOŁEJKO E., KOWALUK-KRUPA A., WYDRO U., BUTAREWICZ A., JABŁONSSKA-TRYPUĆ A., PIEKUT J., DEC D., ŁOBODA T. The assessment of microbiological indoor air quality in bakeries. Inż. Ekolog. 47 (1), 182, 2016 [In Polish].

12. FLANNIGAN B., SAMSON R.A., MILLER J.D. Microorganisms in indoor air. In Microorganisms in home and indoor work environments: Diversity, health impacts, investigation and control, $2^{\text {nd }}$ ed.; Haas C.N., Ed., New York, NY: CRC Press, 25, 2016.

13. KELLEY S.T., GILBERT J.A. Studying the microbiology of the indoor environment. Genome Biol. 14 (2), 202, 2013.

14. PRUSSIN A.J., MARR L.C. Sources of airborne microorganisms in the built environment. Microbiome. 3 (1), 78, 2015.

15. ARSECULERATNE S.N. Surface properties of Aerococcus viridans in relation to virulence. Microb. Ecol. Health Dis. 2 (2), 91, 1989.

16. SZCZERBA I. Micrococci as an etiologic factor of opportunistic infections. Przegl. Epidemiol. 54, 385, 2000 [In Polish].

17. SALEM I.B., SGHAIER H., TRIFI H., HENI S., KHWALDIA K., SAIDI M., LANDOULSI A. Isolation and characterization of a novel Micrococcus strain for bioremediation of strontium in radioactive residues. Afr. J. Microbiol. Res. 6 (4), 851, 2012.

18. HASSAN A.A., MAHGOUB A.M. Salt inducible-proteins and conjugal gene transfer of halotolerant Staphylococcus isolated from salinity soil. Egypt J. Genet. Cytol. 40, 263, 2011.

19. ÖRDÖGH L., HUNYADKÜRTI J., VÖRÖS A., HORVÁTH B., SZÜCS A., URBÁN E., KERESZT A., KONDOROSI É., NAGYA I. Complete genome sequence of Propionibacterium avidum strain 44067, isolated from a human skin abscess. Genome Announc. 1 (3), e00337, 2013.

20. STACKEBRANDT E., SCHUMANN P. Cellulomonas. In Bergey's Manual of Systematics of Archaea and Bacteria; Whitman W.B., Rainey F., Kämpfer P., Trujillo M., Chun J., DeVos P., Hedlund B., Dedysh S., Eds., Hoboken, New Jersey: Wiley, 1, 2015.

21. RODRIQUEZ H., REVERON I., DORIA F., CONSTANTINI A., DE LAS RIVAS B., MUNOZ R., 
GARCIA-MORUNO E. Degradation of Ochrotoxin A by Brevibacterium Species. J. Agric. Food Chem. 59, 10755, 2011.

22. HAN L., LEI J.E., WANG X., GUO L.T., KANG Q.Y., HE L., XU J. Septicemia caused by Leifsonia aquatica in a healthy patient after retinal reattachment surgery. J. Clin. Microbiol. 51 (11), 3886, 2013.

23. PANGALLO D., ŠIMONOVIČOVÁ A., CHOVANOVÁ K., FERIANC P. Wooden art objects and the museum environment: identification and biodegradative characteristics of isolated microflora. Lett. Appl. Microbiol. 45 (1), 87, 2007.

24. TRISTAN A., LINA G., ETIENNE J., VANDENESCH F. Biology and pathogenicity of staphylococci other than Staphylococcus aureus and Staphylococcus epidermidis. In Gram-Positive Pathogens, $2^{\text {nd }}$ ed.; Fischetti A., Novick R.P., Ferretti J.J., Portnoy D.A., Rood J.I., Eds., Washington, D.C.: ASM Press, 572, 2006.

25. CAVANAGH J.P., PAIN M., ASKARIAN F., BRUUN J.A., URBAROVA I., WAI S.N., SCHMIDT F., HOHANNESSEN M. Comparative exoproteome profiling of an invasive and a commensal Staphylococcus haemolyticus isolate. J. Proteom. 197, 106, 2019.

26. HUNG W.C., CHEN H.J., LIN Y.T., TSAI J.C., CHEN C.W., LU H.H., TSENG S.P., JHENG Y.Y., LEONG K.H., TENG L.J. Skin Commensal Staphylococci may act as reservoir for fusidic acid resistance genes. PLoS ONE. 10 (11), e0143106, 2015.

27. FALKIEWICZ-DULIK M., JANDA K., WYPYCH G. Microorganism involved in biodegradation of materials. In Handbook of material biodegradation, biodeterioration and biostablization, $2^{\text {nd }}$ ed.; Falkiewicz-Dulik M., Janda K., Wypych G., Eds., Chemtec Publishing, 7, 2015.

28. JIANG S., ZHENG B., DING W., LV L., JI J., ZHANG H., XIAO Y., LI L. Whole-Genome Sequence of Staphylococcus hominis, an Opportunistic Pathogen. J. Bacteriol. 194 (17), 4761, 2012.

29. SZCZUKA E., TELEGA K., KAZNOWSKI A. Biofilm formation by Staphylococcus hominis strains isolated from human clinical specimens. Folia Microbiol. 60, 1, 2015.

30. VOINEAGU L., BRAGA V., BOTNARCIUC M., BARBU A., TATARU M. Emergence of Staphylococcus hominis strains in general infections. ARS Medica Tomitana, 2 (69), 80, 2012.

31. CAMERON D.R., JIANG J.H., HASSAN K.A., ELBOURNE L.D. H., TUCK K.L., PAULSEN I.T., PELEG A.Y. Insights on virulence from the complete genome of Staphylococcus capitis. Front. Microbiol. 6, 980, 2015.

32. TEVELL S., HELLMARK B., NILSDOTTERAUGUSTINSSON A., SODERQUIST B. Staphylococcus capitis isolated from prothetic joint infections. Eur. J. Clin. Microbiol. Infect. Dis. 36, 115, 2017.

33. STERFLINGER K., PIÑAR G. Microbial deterioration of cultural heritage and works of art-tilting at windmills? Appl. Microbiol. Biotechnol. 97 (22), 9637, 2013.

34. CITRO R., PROTA C., GRECO L., MIRRA M., MASUlLO A., SILVERIO A., BOSSONE E., PISCIONE F. Kocuria kristinae endocarditis related to diabetic foot infection. J. Med. Microbiol. 62, 932, 2013.

35. LAI C.C., WANG J.Y., LIN S.H., TAN C.K., WANG C.Y., LIAO C.H., CHOU C.H., HUANG Y.T., LIN H.I., HSUEH P.R. Catheter-related bacteraemia and infective endocarditis caused by Kocuria species. Clin. Microbiol. Infect. 17, 190, 2011.

36. FRENEY J., HANSEN W., ETIENNE J., FLEURETTE J. Postoperative infant septicemia caused by Pseudomonas luteola (CDC Group Ve-1) and Pseudomonas orzyhabitans (CDC Group Ve-2). J. Clin. Microbiol. 26 (6), 1241, 1998.

37. WOO K.S., CHOI J.L., KIM B.R., KIM J.E., KIM K.H., KIM J.M., HAN J.Y. Outbreak of Pseudomonas oryzihabitans pseudobacteremia related to contaminated equipment in an emergency room of a tertiary hospital in Korea. Infect. Chemother. 46 (1), 42, 2014.

38. TENA D., FERNANDEZ C. Pseudomonas oryzihabitans: an unusual cause of skin and soft tissue infection. Infect. Dis. 47, 820, 2015.

39. NAKANO M., NIWA M., NISHIMURA N. Specific and sensitive detection of Alcaligenes species from an agricultural environment. Microbiol. Immunol. 57, 240, 2013.

40. GUTAROWSKA B. Niszczenie materiałów technicznych przez drobnoustroje. LAB Laboratoria, Aparatura, Badania. 18, 10, 2013 [In Polish].

41. RASMUSSEN M. Aerococci and aerococcal infections. J. Inf. 66, 467, 2013.

42. RASMUSSEN M. Aerococcus: an increasingly acknowledged human pathogen. Clin. Microbiol. Infect. 22, 22, 2016.

43. SIEGMAN-IGRA Y., AZMON Y., SCHWARTZ D. Milleri group streptococcus - a stepchild in the viridans family. Eur. J. Clin. Microbiol. Infect. Dis. 31, 2453, 2012.

44. JUNCKERSTORFF R.K., ROBINSON J.O., MURRAY R.J. Invasive Streptococcus anginosus group infection does the species predict the outcome? Int. J. Infect. Dis. 18, 38, 2014.

45. RAMS T.E., FEIK D., MORTENSEN J.E., DEGENER J.E., VAN WINKELHOFF A.J. Antibiotic susceptibility of periodontal Streptococcus constellatus and Streptococcus intermedius clinical isolates. J. Peridontol. 85 (2), 1792, 2014.

46. CAMPBELL A.W., THRASHER J.D., GRAY M.R., VOJDANI A. Mold and mycotoxins: effects on the neurological and immune systems in humans. Adv. Appl. Microbiol. 55, 375, 2004.

47. NIELSEN K.F. Mycotoxin production by indoor molds. Fungal Genet. Biol. 39 (2), 103, 2003.

48. GÓRNY R.L. Wilgoć jako kluczowy czynnik inicjujący skażenie mikrobiologiczne budynków. In Zniszczenia wodne budynków i ich korozja mikrobiologiczna. Przyczyny, zagrożenia, prewencja i remediacja; Górny R.L., Ed., Central Institute for Labour Protection National Research Institute, 22, 2010 [In Polish].

49. AMAIKE S., KELLER N.P. Aspergillus flavus. Annu. Rev. Phytopathol. 49, 107, 2011.

50. AMARE M.G., KELLER N.P. Molecular mechanisms of Aspergillus flavus secondary metabolism and development. Fungal Genet. Biol. 66, 11, 2014.

51. JANIŃSKA B. Historic buildings and mould fungi: not only vaults are menacing with "Tutankhamen's curse". Foundations of Civil and Environmental Engineering, 2, 43, 2002.

52. MILANI J.M. Ecological conditions affecting mycotoxin production in cereals: a review. Vet. Med. 58 (8), 405, 2013.

53. TASIĆ S., MILADINOVIĆ-TASIĆ N. Cladosporium spp.: cause of opportunistic mycoses. Acta Fac. Med. Naiss. 24 (1), 15, 2007.

54. GRINN-GOFROŃ A., STRZELCZAK A. Changes in concentration of Alternaria and Cladosporium spores during summer storms. Int J Biometeorol, 57, 759, 2013.

55. HMIEL M.J., FRĄCZEK K., GRZYB J. The problems of microbiological air contamination monitoring. 
Woda-Środowisko-Obszary Wiejskie. 15 (1), 17, 2015 [In Polish].

56. GUTAROWSKA B. Grzyby strzępkowe zasiedlające materiały budowlane - wzrost oraz produkcja mikotoksyn i allergenów. Scientific Bulletin of the Technical University of Lodz. 398, 3, 2010 [In Polish].

57. WISZNIEWSKA M., WALUSIAK-SKORUPA J., PANNENKO I., DRANIAK M., PALCZYNSKI C. Occupational exposure and sensitization to fungi among museum workers. Occup. Med. 59 (4), 237, 2009.
58. SZOSTAK-KOT J. Microbiological hazards of museum and library collections. Conservation chemistry. Materials for students of the Jagiellonian University, Krakow, 2010.

59. WISZNIEWSKA M., WALUSIAK J., GUTAROWSKA B., ŻAKOWSKA Z., PAŁCZYŃSKI C. Moulds occupational and environmental hazards. Med. Pr. 55 (3), 257, 2004 [In Polish].

60. World Health Organization (WHO). Air Quality Guidelines for Europe. $2^{\text {nd }}$ ed, WHO Regional Publications, European Series, no. 91, WHO Regional Office for Europe, Copenhagen, 2000. 